\title{
Inoculation and Soil Texture Effects on Yield and Yield Components of Mungbean
}

\author{
Andre A. Diatta ${ }^{1}$, Wade E. Thomason ${ }^{1}$, Ozzie Abaye ${ }^{1}$, Larry J. Vaughan ${ }^{2}$, Thomas L. Thompson ${ }^{3}$, Mamadou Lo ${ }^{4}$, \\ Bee K. Chim ${ }^{1} \&$ Sarah Bateman ${ }^{1}$ \\ ${ }^{1}$ Department of Crop \& Soil Environmental Sciences, Virginia Polytechnic Institute \& State University, \\ Blacksburg, USA \\ ${ }^{2}$ Center for International Research, Education and Development, Virginia Polytechnic Institute \& State \\ University, Blacksburg, USA \\ ${ }^{3}$ College of Agriculture and Life Sciences, Virginia Polytechnic Institute \& State University, Blacksburg, USA \\ ${ }^{4}$ Centre National de Recherches Agronomiques, Institut Sénégalais de Recherches Agricoles, Diourbel, Sénégal \\ Correspondence: Andre A. Diatta, Department of Crop \& Soil Environmental Sciences, Virginia Polytechnic \\ Institute \& State University, 330 Smyth Hall, 185 Ag Quad Lane, Blacksburg, VA 24061, USA. Tel: \\ 1-314-807-0734.E-mail: andre22@vt.edu
}

Received: April 26, 2018

Accepted: June 3, $2018 \quad$ Online Published: August 15, 2018

doi:10.5539/jas.v10n9p6

URL: https://doi.org/10.5539/jas.v10n9p6

\begin{abstract}
Mungbean [Vigna radiata (L.) Wilczek] is a short-duration and relatively drought-tolerant crop grown predominantly in the tropics. This grain legume can improve soil fertility through biological nitrogen $(\mathrm{N})$ fixation. To assess the effects of Bradyrhizobium (group I) inoculation on yield and yield attributes of mungbean, a greenhouse study was conducted during Fall 2016 with two mungbean cultivars ('Berken' and 'OK2000'), two inoculum treatments (inoculated and uninoculated), and two soil textures (loamy sand and silt loam). Pots were laid out in a completely randomized design and treatment combinations were replicated seven times. The main effects of cultivar and soil texture significantly $(P \leq 0.05)$ affected mungbean seed weight and plant residue mass Seed yield (13\%), plant residue (22\%), and protein content $(6 \%)$ of OK2000 were significantly higher than Berken cultivar. A $31 \%$ seed yield and $40 \%$ plant residue increase were recorded on silt loam soil compared to loamy sand soil. Significant increase in plant height $(18 \%)$ and number of pods per plant $(21 \%)$ were also recorded when mungbean plants were grown on silt loam compared to loamy sand soil. Bradyrhizobium inoculation significantly increased the number of pods per plant, the number of seeds per plant, and seed yield. $[$ Cultivar $\times$ inoculation] and [cultivar $\times$ soil texture] interactions had significant $(P \leq 0.05)$ effects on number of seeds per pods and plant height, respectively. Understanding the agronomic practices and soil physical properties that may limit mungbean production could help in optimizing its establishment and growth in non-traditional growing areas.
\end{abstract}

Keywords: Bradyrhizobium inoculation, yield, soil texture, Vigna radiata L., yield

\section{Introduction}

Mungbean [Vigna radiata (L.) Wilczek], also known as mung, moong, green gram, golden gram, chickasaw pea, oregon pea, and chop suey bean, is a pulse species widely grown in tropical and sub-tropical regions of the world (Nair et al., 2013). It is an ancient crop believed to be a native of India and is extensively cultivated in South, East, and Southeast Asia, as well as East Africa (Kim, Nair, J. Lee, \& S.-H. Lee, 2015; Sharma, Priya, Bindumadhava, Nair, \& Nayyar, 2016). Mungbean is an important food and livestock feed legume crop in these regions and is consumed for its protein-rich seeds (Dahiya et al., 2015; Foyer et al., 2016). Mungbean, a short growth duration legume (55-110 days), fixes atmospheric $\mathrm{N}$ through a symbiotic association with rhizobia living in its root nodules (Peoples \& Herridge, 1990; Razzaque, Haque, Karim, \& Solaiman, 2016). However, under unfavorable conditions such as very acidic and heavy-textured soils, or very hot, dry conditions, Rhizobium survival and crop establishment can be constrained, thereby limiting root nodulation and yield (Kirchhof \& So, 1995; Rahmianna, Adisarwanto, Kirchhof, \& So, 2000). Therefore, seed inoculation with a strain of Rhizobium, 
appropriate to the cultivar and soil texture is recommended for improving growth and yield of mungbean (Hussain et al., 2014; Sharma \& Khanna, 2010).

Anjum, Ahmed, and Rauf (2006) reported that Rhizobium inoculation of mungbean seeds increased the number of pods per plant, number of seeds per plant, seed weight and seed yield over the control. Rhizobium inoculation also increased plant height, number of nodules per plant, number of pods per plant, number of seeds per pod and weight of seeds per plant, and $\mathrm{N}$ and phosphorous (P) accumalation compared to the control (Hussain et al., 2014). Molla, Solaiman, Jahiruddin, Mridha, and Khanam (2011) observed that inoculation of seed with Rhizobium produced a higher number of nodules per plant, plant height, number of pod per plant and seed yield. Travlos and Karamanos (2006) compared the responses of marama bean [Tylosema esculentum (Burch.) A. Schreib.], a perennial tropical grain legume of southern Africa on four different soil textures. They reported significant restriction in marama bean growth under clay and clay loam soils compared to sandy clay loam, and sandy soils. Thomson, Siddique, Barr, and Wilson (1997) evaluated the growth and seed yields of six commercially grown and eight potential new grain legumes species on a sandy clay loam and silty clay loam. They observed that faba bean (Vicia faba) cv. Fiord and field pea (Pisum sativum L.) cv. Dundale had the highest grain yield compared to other legume species on fine-textured, neutral to alkaline soils.

Most previous studies have shown that the use of a short-duration legume crop such as mungbean could be useful for producing nutrient-rich foods under various agronomic practices in regions facing food insecurity issues. However, few studies have investigated the yield performance of mungban cultivars as affected by Bradyrhizobium inoculants under various soil conditions. The present study evaluated the combined effects of Bradyrhizobium (group I) inoculation, cultivar, and soil texture on yield and yield components of mungbean under greenhouse conditions.

\section{Materials and Methods}

\subsection{Soil Description}

A Eunola loamy sand and a Guernsey silt loam soil from 0-15 cm depth were collected from Virginia Tech's Tidewater Agricultural Research and Extension Center in Suffolk, VA $\left(36^{\circ} 39^{\prime} 50.9^{\prime \prime} \mathrm{N}\right.$ latitude, $76^{\circ} 44^{\prime} 01.0^{\prime \prime} \mathrm{W}$ longitude) and Kentland Agricultural Research Farm in Blacksburg, VA $\left(37^{\circ} 11^{\prime} 47.3^{\prime \prime} \mathrm{N}\right.$ latitude, $80^{\circ} 34^{\prime} 49.7^{\prime \prime} \mathrm{W}$ longitude), respectively. The site in Suffolk had been under a corn (Zea mays L.) and cotton (Gossypium hirsutum L.) rotation while the one in Blacksburg was subjected to a continuous corn system. The presence of naturally occurring symbiotic bacteria in these samples was not evaluated, but due to the lack of legumes in either of these rotations, the presence of high levels of native bacteria was deemed unlikely. The field capacity of the soil samples was determined as described by Gupta and Larson (1979). Soil pH and plant available Ca, Mg, P, and $\mathrm{K}$ and were determined as described by Maguire and Heckendorn (2011). Soil $\mathrm{pH}$ was determined using a 1:1 (vol/vol) soil-water mix. Phosphorus and potassium were determined via extraction with Mehlich 1 at a 1:1 solution:soil ratio, (Mehlich, 1976) filtered (Whatman \#2), and analyzed via inductively coupled plasma atomic emission spectroscopy (ICP) (SPECTRO ARCOS, Kleve, Germany). Total C and N were analyzed by dry combustion using a vario MAX CNS Element Analyzer (Elementar Analysensysteme GmbH, Hanau, Germany). Prior to determining the concentrations of ammonium $\left(\mathrm{NH}_{4}{ }^{+}\right)$and nitrate $\left(\mathrm{NO}_{3}{ }^{-}\right)$using Lachat QuikChem AE flow-injection autoanalyzer and ion chromatography, the soil samples were prepared as described by Bremner and Keeney (1966). The physical and chemical properties of the two soil types are presented in Table 1. 
Table 1. Chemical and physical characteristics of the Eunola soil and Guernsey soil

\begin{tabular}{lll}
\hline Soil properties & Eunola soil & Guernsey soil \\
\hline Soil texture & Loamy sand & Silt loam \\
Field Capacity (\%) & 9 & 17 \\
Soil pH & 5.9 & 6.2 \\
$\mathrm{C}(\%)$ & 0.98 & 0.93 \\
$\mathrm{~N}(\%)$ & 0.08 & 0.08 \\
$\mathrm{C} / \mathrm{N}$ & 13 & 11 \\
$\mathrm{NO}_{3}^{-}(\mathrm{mg} / \mathrm{kg})$ & 1.52 & 2.67 \\
$\mathrm{NH}_{4}^{+}(\mathrm{mg} / \mathrm{kg})$ & 0.32 & 0.25 \\
$\mathrm{P}_{\text {plant available }(\mathrm{mg} / \mathrm{kg})}$ & 37 & 25.67 \\
$\mathrm{~K}$ plant available $(\mathrm{mg} / \mathrm{kg})$ & 62.67 & 61.33 \\
$\mathrm{Ca}$ plant available $(\mathrm{mg} / \mathrm{kg})$ & 575 & 858.67 \\
Mg plant available $(\mathrm{mg} / \mathrm{kg})$ & 72 & 167 \\
\hline
\end{tabular}

Note. $\mathrm{pH}$ : soil (1:1 soil: deionized water mixture on a volumetric basis); Total carbon (C) and total nitrogen (N): vario MAX CNS Element Analyzer; Inorganic $\mathrm{NO}_{3}{ }^{-}$and $\mathrm{NH}_{4}{ }^{+}: 2 \mathrm{M} \mathrm{KCl}$ extraction; Plant available nutrients: soil (Mehlich 1 solution).

\subsection{Experimental Design and Management}

A greenhouse study was conducted at a Virginia Tech greenhouse in Blacksburg (Virginia, USA) to examine the yield responses of mungbean cultivars to Bradyrhizobium inoculation and soil type. The experiment consisted of two mungbean cultivars, 'Berken' and 'OK2000', two inoculum treatments (inoculated and uninoculated conditions), and two soil textures (loamy sand and silt loam). The treatments were a factorial combination of three factors and the experiment was laid out as a completely randomized design with seven replications (Table 2).

Table 2. Cultivars, inoculation treatments, and soil texture used in the pot experiment

\begin{tabular}{llll}
\hline \multirow{2}{*}{ No. } & \multicolumn{2}{c}{ Treatments } \\
\cline { 2 - 4 } & Cultivars & Inoculation & Soil Texture \\
\hline 1. & Berken & Inoculated & Loamy sand \\
2. & Berken & Inoculated & Silt loam \\
3. & Berken & Uninoculated & Loamy sand \\
4. & Berken & Uninoculated & Silt loam \\
\hdashline 5. & OK2000 & Inoculated & Loamy sand \\
6. & OK2000 & Inoculated & Silt loam \\
7. & OK2000 & Uninoculated & Loamy sand \\
8. & OK2000 & Uninoculated & Silt loam \\
\hline
\end{tabular}

Mungbean seeds were mixed at a rate of $10 \mathrm{~g}$ inoculant $\mathrm{kg}^{-1}$ seed with Bradyrhizobium inoculum (group I) purchased from Hancock Farm \& Seed Co., Inc. (Dade City, FL, USA) to allow thorough coating and sown in the pots. The seed inoculant contained less than $1 \%$ of active ingredients by weight of Bradyrhizobium sp. (Vigna), Bradyrhizobium japonicum, Rhizobium leguminosarum biovar phaseoli, Rhizobium leguminosarum biovar viceae and $99 \%$ of inactive ingredients. Mungbean cultivars were obtained from Oklahoma Foundation Seed Stocks (Stillwater, OK, USA). Berken is a medium-large seeded cultivar while OK2000 is a large-seeded cultivar with good lodging and shattering resistance. Berken is widely grown and has $15 \%$ lower seed weight than OK2000 with similar seed yields. Experimental pots $\left(19 \mathrm{~cm}\right.$ tall, $19 \mathrm{~cm}$ outside diameter, and $3785 \mathrm{~cm}^{3}$ volume) were lined with polythene bags to avoid loss of water and filled with $4 \mathrm{~kg}$ of soil. Three seeds were sown (immediately after inoculation if applicable) per pot by hand at 3-4 cm depth on December 9, 2016 and grown at $80 \%$ field capacity. After seedling emergence, density was thinned to one plant per pot. Plant height was measured with a ruler at harvest maturity (March 14, 2017) by stretching out the plant to the tip. At full maturity, mungbean pods were hand harvested twice and number of pods per plant and number of seeds per pod 
were counted. Seed yield was calculated as dry matter of seeds from each plant at harvest and seed yield per plant was computed. For plant dry matter determination, aboveground plant material was collected after seed harvest and oven dried at $50{ }^{\circ} \mathrm{C}$ to constant weight. Seed protein content was estimated using near infrared spectroscopy.

Analysis of variance (ANOVA) was used to test the effects of cultivar, Bradyrhizobium inoculation, and soil texture on plant parameters, seed yield and yield components using JMP Pro version 13.0.0 statistical software (SAS Institute Inc., Carey, NC). Differences among means were considered significant at the $\alpha=0.05$ level of probability and were separated using Fisher's protected LSD. Most interactions were not significantly different for yield and yield components of mungbean, therefore most main effects were subjected to mean separation tests.

\section{Results and Discussion}

\subsection{Plant Height at Maturity}

The comparison of loamy sand with silt loam revealed that the average plant height $(28.7 \mathrm{~cm})$ of plants grown in silt loam soil was $18 \%$ greater than average height of plants grown in loamy sand soil (Figure 1). These results are in agreement with Singh et al. (2011) who reported differences on mungbean growth when grown in different soil textures. They observed greater plant height on a sandy loam soil compared to a loamy sand soil and attributed this to higher organic carbon and moisture content in the sandy loam. Results obtained by Ntukamazina et al. (2017) revealed that differences in mungbean growth under different soils may be due to variations in moisture retention of soils. Increased height of plants grown in silt loam soils can likely be explained by better tilth compared to the sandy loam soil. Previous findings have demonstrated that different soil structures can result in differences in particle composition, chemical properties, mechanical impedance and bulk density which affect crop growth and development (Cook, Gupta, Woodhead, \& Larson, 1995; Travlos \& Karamanos, 2006).

Table 3. Analysis of variance of the effects of Bradyrhizobium inoculation, cultivar, and soil texture and their interactions on yield and yield components of mungbean ( $\mathrm{n}=7$ per treatment)

\begin{tabular}{|c|c|c|c|c|c|c|}
\hline Treatments & Plant height & No. pods & No. seeds & Seed weight & Plant residue & Protein \\
\hline & ----- cm ----- & \multicolumn{2}{|c|}{--------- plant ${ }^{-1}$--------- } & \multicolumn{2}{|c|}{------------ g plant ${ }^{-1}$------------ } & --- \% --- \\
\hline & \multicolumn{6}{|c|}{$\operatorname{Pr}>f$} \\
\hline Cultivar & $<.0001$ & 0.8028 & 0.6637 & 0.0029 & $<.0001$ & 0.0003 \\
\hline Inoculation & 0.2831 & 0.0029 & 0.0032 & 0.0013 & 0.0583 & 0.3178 \\
\hline Soil Texture & $<.0001$ & $<.0001$ & $<.0001$ & $<.0001$ & $<.0001$ & 0.3520 \\
\hline Cultivar*Inoculation & 0.0247 & 0.3838 & 0.5031 & 0.8632 & 0.3995 & 0.6197 \\
\hline Cultivar*Soil Texture & 0.8587 & 0.0657 & 0.0066 & 0.1036 & 0.8453 & 0.6134 \\
\hline Inoculation*Soil Texture & 0.3554 & 0.6178 & 0.3362 & 0.2497 & 0.3107 & 0.7109 \\
\hline Cultivar*Inoculation*Soil Texture & 0.7590 & 0.1384 & 0.0501 & 0.0672 & 0.6806 & 0.9616 \\
\hline
\end{tabular}

The cultivar and inoculation interaction was statistically significant for plant height (Table 3). Height of inoculated OK2000 plants was greater than uninoculated OK2000 plants (30.0 vs. $26.8 \mathrm{~cm}$, respectively) while inoculated and uninoculated Berken plants did not differ from each other $($ mean $=23.9 \mathrm{~cm})$ (Figure 2). Similar results were reported by Bhuiyan, Mian, and Islam (2008) who observed greater plant height for inoculated BARI Mung-2 cultivar due to increased nodulation resulting in enhanced vegetative growth. 


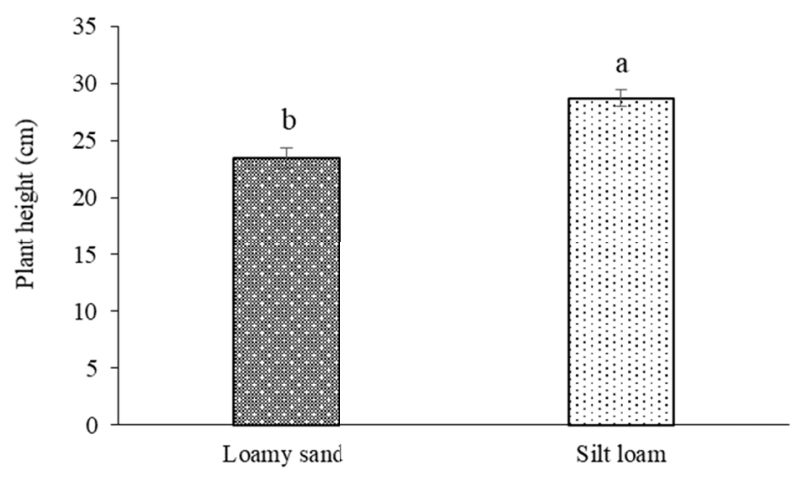

Figure 1. Effect of soil texture on plant height. Treatments with the same letter are not significantly different according to Fisher's protected LSD $(\alpha=0.05)$. Error bars show standard error of the mean $(n=56)$

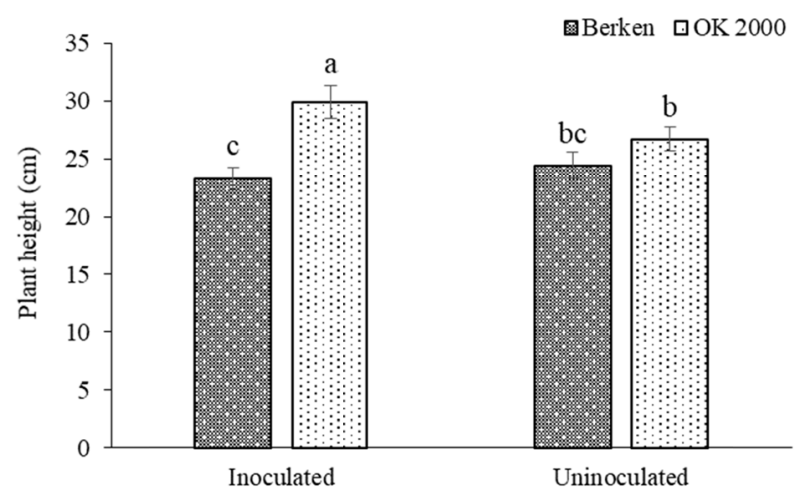

Figure 2. Effect of cultivar on plant height of mungbean grown in soil with and without Bradyrhizobium (group I) inoculation. Treatments with the same letter are not significantly different according to Fisher's protected LSD $(\alpha=0.05)$. Error bars show standard error of the mean $(n=56)$

\subsection{Number of Pods per Plant}

Bradyrhizobium inoculation and soil texture significantly affected mungbean pod formation (Table 3). Over cultivars and soil textures, the maximum number of pods (12 pods/plant) was observed for inoculated mungbean (a 15\% increase) compared to uninoculated plants (Table 4). Anjum et al. (2006) found similar results when studying the impact of Rhizobium inoculation on mungbean and reported that inoculation with Rhizobium increased the number of pods per plant over the control. A pot experiment performed by Hussain et al. (2014) to determine the response of mungbean nodulation, growth and yield to Rhizobium inoculation revealed a 50\% increase in the number of pods per plant compared to the control.

The comparison of the pod number per plant indicated that mungbean grown in silt loam soil had, on average, 12 pods/plant which represents a $21 \%$ increase compared to mungbean grown in loamy sand soil (Table 4). Similar results were obtained by Oke and Eyitayo (2010) when evaluating cowpea (Vigna unguiculata L. Walp.) growth under different fallow soils in Nigeria. They reported a significantly greater number of pods for plants grown in a sandy clay loam than a clay loam or sandy loam. Enhancement of pod formation under these soil textures could be attributed to greater concentration of organic matter, higher $\mathrm{pH}$, greater percentage of exchangeable cations and greater water and fertilizer retention. The significant differences on number of pods per plant reported in our study can be attributed to the favorable conditions of silt loam soil for mungbean development. Some researchers, confirming our present results, also compared the number of pods per plant of legumes on different soil textures and reported a significant effect evidencing its importance on legume growth and yield (Ndema, Etame, Taffouo, \& Bilong, 2010; Zhao, Jia, Y. Wang, M. Wang, \& McGiffen Jr., 2015). 
Table 4. Main effects of cultivar, inoculation, and soil texture on number of pods, seed weight, and plant residue weight per plant

\begin{tabular}{lllll}
\hline Treatments & & No. pods & Seed weight $(\mathrm{g})$ & Plant residue $(\mathrm{g})$ \\
\hline Cultivar & Berken & $10.79 \pm 0.40 \mathrm{a}$ & $3.70 \pm 0.21 \mathrm{~b}$ & $2.48 \pm 0.18 \mathrm{~b}$ \\
& OK2000 & $10.93 \pm 0.40 \mathrm{a}$ & $4.25 \pm 0.18 \mathrm{a}$ & $3.18 \pm 0.18 \mathrm{a}$ \\
\hline Inoculation & Inoculated & $11.75 \pm 0.50 \mathrm{a}$ & $4.28 \pm 0.20 \mathrm{a}$ & $2.99 \pm 0.12 \mathrm{a}$ \\
& Uninoculated & $9.96 \pm 0.44 \mathrm{~b}$ & $3.68 \pm 0.20 \mathrm{~b}$ & $2.67 \pm 0.12 \mathrm{a}$ \\
\hline Soil texture & Loamy sand & $9.61 \pm 0.45 \mathrm{~b}$ & $3.24 \pm 0.16 \mathrm{~b}$ & $2.12 \pm 0.12 \mathrm{~b}$ \\
& Silt loam & $12.11 \pm 0.43 \mathrm{a}$ & $4.72 \pm 0.13 \mathrm{a}$ & $3.54 \pm 0.15 \mathrm{a}$ \\
\hline
\end{tabular}

Note. For each parameter, means within each treatment followed by different letter are significantly different [Fisher's protected LSD $(\alpha=0.05)$ ].

\subsection{Number of Seeds per Plant}

The number of seeds per plant was significantly affected by mungbean inoculation (Table 3). Mungbean inoculation increased the number of seeds per plant of inoculated plants by $18 \%$ compared to uninoculated plants to an average of 84 seeds/plant (Figure 3). Hussain et al. (2014) evaluated the effects of Rhizobium inoculation on yield and yield attributes of mungbean. They found that inoculation significantly increased (23\%) the number of seeds per pods compared to uninoculated plants. However, a study conducted by Kyei-Boahen, Savala, Chikoye, and Abaidoo (2017) on growth and yield responses of cowpea revealed that inoculation did not significantly increase number of seeds per pod compared to uninoculated plants on a Rhodic Ferralsol. The differences in number of seeds per plant of mungbean reported in our study could be attributed to genotypic differences (Peksen, Toker, Ceylan, Aziz, \& Farooq, 2015; Razzaque et al., 2016).

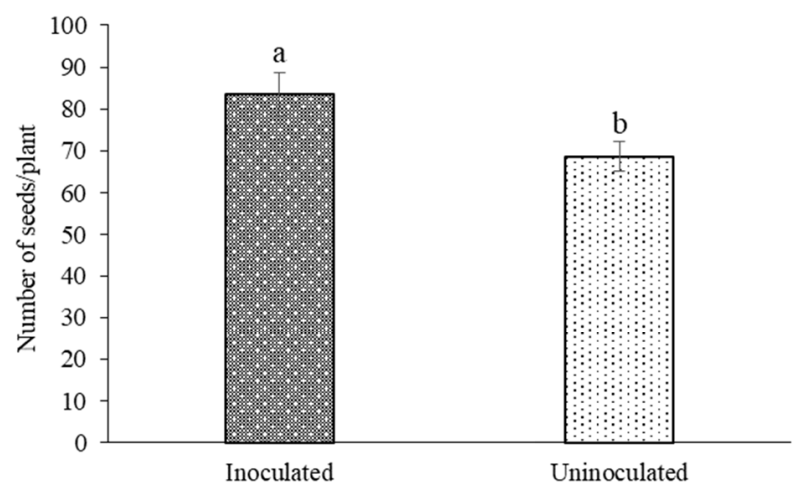

Figure 3. Effect of inoculation on number of seeds per plant of mungbean. Different letters on bars means significant difference between treatment according to Fisher's protected LSD $(\alpha=0.05)$. Error bars show standard error of the mean $(n=56)$

The interaction effect of cultivar and soil texture on number of seeds per plant was statistically significant (Table 3). Figure 4 shows that the greatest number of seeds was recorded for Berken grown in silt loam soil with 95 seeds per pod while Berken grown in loamy sand produced the lowest number of seeds per plant ( 55 seeds/plant). Eugegrave, Jacques, Désiré, and Paul (2010) showed in their study that yield of cowpea significantly increased in plots with sandy clay loam with high sand content $(72 \%)$, organic matter and exchangeable cations. In our study, the difference in number of seeds per plant can be explained by better performance of Berken in silt loam soil. Previous findings (Ahmad et al., 2015; Kumar \& Sharma, 2009) have shown that higher seed yield of mungbean cultivars under different soil textures might be due to greater root system development and a subsequent increase in water and nutrient uptake. 


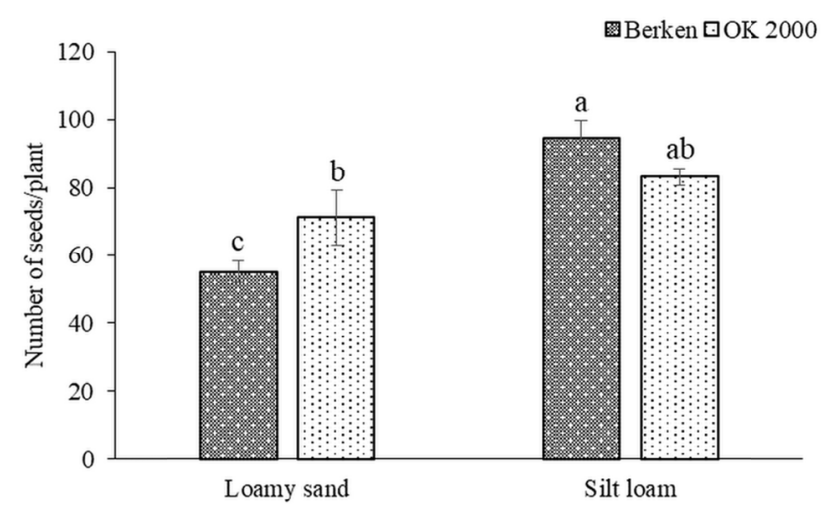

Figure 4. Effect of cultivar on number of seeds per plant of mungbean grown on a loamy sand and silt loam soils. For each soil texture, bars with the same letter are not significantly different according to Fisher's protected LSD $(\alpha=0.05)$. Error bars show standard error of the mean $(n=56)$

\subsection{Seed Weight}

The seed weight of mungbean (g/plant) was significantly affected by cultivar, inoculation, and soil texture (Table 3 ). Among cultivars, the maximum seed weight of $4.25 \mathrm{~g}$ per plant was observed for OK2000 and represented a 13\% increase compared to Berken (Table 4). M. Begum, M. Begum, Anwar, and Juraimi (2009) also studied the effect of cultivar on morphological characters, yield attributes and yield of mungbean varieties and reported BINA moog7 cultivar had the highest seed yield per plant compared to other varieties. Variations in yield among mungbean cultivars could be attributed to hereditary superiority, higher yield potential and greater translocation of nutrients (Ahmad et al., 2015; Sriphadet, Lambrides, \& Srinives, 2007).

Inoculation of mungbean resulted in a $14 \%$ increase compared to uninoculated mungbean (3.68 g/plant) while growing in the silt loam soil resulted in a $31 \%$ increase in seed weight compared to the loamy sand (3.24 g/plant) (Table 4). Similar results were reported by Bhuiyan et al. (2008) who investigated the response of mungbean cultivars to Bradyrhizobium inoculation and reported significant increase $(27 \%)$ in seed yield over control. The high yields of mungbean under bacterial inoculation could be attributed to plant growth promoting substances in the rhizosphere and efficient nutrient uptake resulting in increased dry matter accumulation and greater photosynthate translocation to the seed (Zaidi, Khan, \& Aamil, 2004). The field study conducted by Stajković-Srbinović, Kuzmanović, Mrvić, and Knežević-Vukčević (2011) to explore growth and yield components of mungbean under different soil types showed a $24 \%$ increase in bean yield in a clay loam soil compared to a heavy clay soil. Low seed yield of mungbean in heavy clay could be explained by reduced infiltration and slow drainage due to the prevalence of small pores in soil.

\subsection{Bean Plant Residue Weight}

The means presented in Table 4 showed that OK2000 had the highest plant residue biomass (3.18 g) which was $22 \%$ greater than Berken. This result is in accordance with Bhuiyan et al. (2008) who reported that BARI Mung-2 mungbean cultivar produced significantly higher stover yield than two local mungbean cultivars. Mondal et al. (2012) demonstrated that higher production of plant residue in mungbean could be attributed to larger leaf area, greater branches per plant and increased plant height.

Residue mass of mungbean plants was also significantly affected by soil texture. Mungbean plants grown in the silt loam soil produced $40 \%$ more residue $(3.54 \mathrm{~g})$ than those plants grown in loamy sand soil. Similar to our results, Stajković-Srbinović et al. (2011) reported differences in the shoot dry yield of mungbean when grown under different soil conditions. They noted greater shoot dry matter of mungbean in clay loam texture compared to heavy clay soil. Cook et al. (1995) demonstrated from growth chamber and field experiments that high soil resistance characteristic of fined-textured soils could explain constraints to biomass production of mungbean. Zhao et al. (2015) reported that lower dry matter accumulation of peanut (Arachis hypogaea L.) on sandy soil compared to loam and clay soils was likely due to poor soil fertility in the sandy soil.

\subsection{Protein Content}

Seed protein content was significantly different between cultivars (Table 3 ). Maximum protein content (25\%) was obtained with the mungbean cultivar OK2000 which was $6 \%$ greater than the protein concentration of 
Berken (Figure 5). The critical review on the technological and nutritional potential of mungbean conducted by Dahiya et al. (2015) revealed variations in the reported protein concentrations ranging from $15-33 \%$ with a mean of 24\%. Bhardwaj and Hamama (2016), however, observed no significant effects of cultivar on protein concentration of Berken and TexSprout seeds. Varietal differences in mungbean seed protein content are likely explained by differences in genetic constitution as reported by Hussain, Malik, Haji, and Malghani (2011), and Paul, Mozumder, Sayed, Akhtaruzzaman, and Akhtaruzzaman (2011).

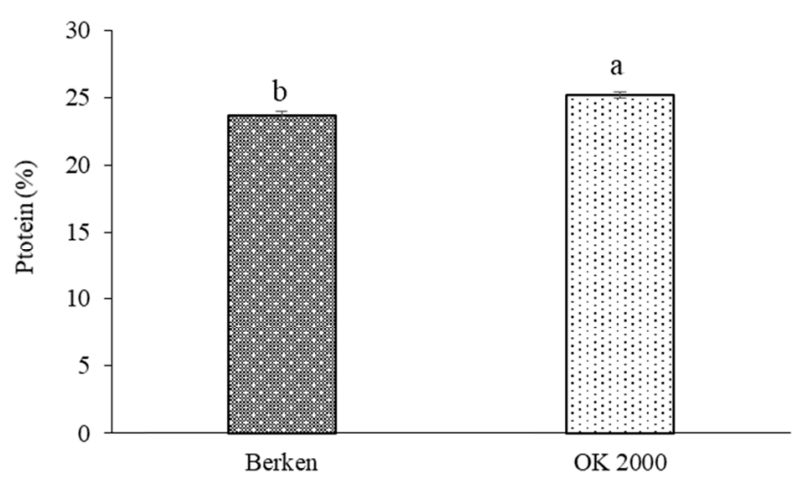

Figure 5. Effect of cultivar on protein content. Different letters on bars means significant difference between treatment according to Fisher's protected LSD $(\alpha=0.05)$. Error bars show standard error of the mean $(n=56)$

\section{Conclusions}

Bradyrhizobium (group I) inoculation, cultivar, and soil texture affect yield and yield components of legume crops. The combined effects of Berken and OK2000 cultivars, two inoculum treatments, and two soil textures investigated under greenhouse conditions indicated significant differences in yield and yield attributes of mungbean. Inoculation of OK2000 cultivar grown on silt loam soil seems a promising agronomic practice for improving yield of mungbean. Bradyrhizobium inoculation increased the number of pods and the number of seeds per plant, but did not increase seed weight indicating compensation by the plant. Plant height at maturity was greater when OK2000 was inoculated, but inoculation did not affect mature height of Berken mungbean indicating differential response by cultivar. Mungbean productivity was frequently influenced by soil texture with greater number of pods, seed weight and plant residue weight for plants grown in silt loam soil. These results indicating the significant effects of soil texture, inoculation, and cultivar on mungbean yield need to be confirmed by field experiments.

\section{Acknowledgements}

The authors are grateful to the Department of Crop \& Soil Environmental Sciences of Virginia Polytechnic Institute \& State University for its contribution, technical expertise, and financial assistance. We also acknowledge the U.S. Agency for International Development-Education and Research in Agriculture project in Senegal for their support.

\section{References}

Ahmad, S., Ali Khan, A., Ali, S., Ullah, I., Imran, M., \& Habibullah, M. (2015). Impact of Phoshporus Levels on Yield and Yield Attributes of Mungbean Cultivars under Peshawar Valley Conditions. J. Environ. Earth Sci., 5, 18-24.

Anjum, M., Ahmed, Z., \& Rauf, C. A. (2006). Effect of Rhizobium inoculation and nitrogen fertilizer on yield and yield components of mungbean. Int. J. Agric \& Biol., 8(2), 238-240.

Begum, M., Begum, M., Anwar, M., \& Juraimi, A. (2009). Optimizing seed rate for summer mungbean varieties. J. Agric. Soc. Sci, 5, 114-118.

Bhardwaj, H. L., \& Hamama, A. A. (2016). Cultivar, planting date, and row spacing effects on mungbean seed composition. Journal of Agricultural Science, 8(10), 26-32. https://doi.org/10.5539/jas.v8n10p26

Bhuiyan, M., Mian, M., \& Islam, M. (2008). Studies on the effects of Bradyrhizobium inoculation on yield and yield attributes of mungbean. Bangladesh Journal of Agricultural Research, 33(3), 449-457. https://doi.org/ 10.3329/bjar.v33i3.1604 
Bremner, J. M., \& Keeney, D. R. (1966). Determination and isotope-ratio analysis of different forms of nitrogen in soils: 3. Exchangeable ammonium, nitrate, and nitrite by extraction-distillation methods. Proceedings. Soil Science Society of America, 30, 577-582. https://doi.org/10.2136/sssaj1966.03615995003000050015x

Cook, S., Gupta, S., Woodhead, T., \& Larson, W. (1995). Soil physical constraints to establishment of mungbeans (Vigna radiata L. Wilczek) in paddy rice (Oryza sativa L.) soils. Soil and Tillage Research, 33(1), 47-64. https://doi.org/10.1016/0167-1987(94)00431-D

Dahiya, P. K., Linnemann, A. R., Van Boekel, M. A. J. S., Khetarpaul, N., Grewal, R. B., \& Nout, M. J. R. (2015). Mung Bean: Technological and Nutritional Potential. Critical Reviews in Food Science and Nutrition, 55(5), 670-688. https://doi.org/10.1080/10408398.2012.671202

Eugegrave, N. N., Jacques, E., Désiré, T. V., \& Paul, B. (2010). Effects of some physical and chemical characteristics of soil on productivity and yield of cowpea (Vigna unguiculata L. Walp.) in coastal region (Cameroon). African Journal of Environmental Science and Technology, 4(3), 108-114. https://doi.org/ 10.5897/AJEST09.160

Foyer, C. H., Lam, H., Nguyen, H. T., Siddique, K. H. M., Varshney, R. K., Colmer, T. D., ... Considine, M. J. (2016). Neglecting legumes has compromised human health and sustainable food production. Nature Plants, 2(8), 16112. https://doi.org/10.1038/nplants.2016.112

Gupta, S. C., \& Larson, W. E. (1979). Estimating soil water retention characteristics from particle size distribution, organic matter percent, and bulk density. Water Resources Research, 15(6), 1633-1635. https://doi.org/10.1029/WR015i006p01633

Hussain, A., Ali, A., Khaliq, T., Ahmad, A., Aslam, Z., \& Asif, M. (2014). Growth, nodulation and yield components of mung bean (Vigna radiata) as affected by phosphorus in combination with rhizobium inoculation. African Journal of Agricultural Research, 9(30), 2319-2323. https://doi.org/10.5897/ AJAR11.691

Hussain, F., Malik, A., Haji, M., \& Malghani, A. (2011). Growth and yield response of two cultivars of mungbean (Vigna radiata L.) to different potassium levels. J. Anim. Plant Sci, 21(3), 622-625.

Kim, S. K., Nair, R. M., Lee, J., \& Lee, S.-H. (2015). Genomic resources in mungbean for future breeding programs. Frontiers in Plant Science, 6, 626. https://doi.org/10.3389/fpls.2015.00626

Kirchhof, G., \& So, H. (1995). The effect of puddling intensity and compaction on soil properties, rice and mungbean growth: A mini-ricebed study. In G. Kirchhof \& H. B. So (Eds.), Management of clay soils for rainfed lowland rice-based cropping systems (pp. 51-70). Canberra: ACIAR.

Kumar, A., \& Sharma, K. (2009). Physiological responses and dry matter partitioning of summer mungbean (Vigna radiata L.) genotypes subjected to drought conditions. Journal of Agronomy and Crop Science, 195(4), 270-277. https://doi.org/10.1111/j.1439-037X.2009.00373.x

Kyei-Boahen, S., Savala, C. E., Chikoye, D., \& Abaidoo, R. (2017). Growth and yield responses of cowpea to inoculation and phosphorus fertilization in different environments. Frontiers in Plant Science, 8, 646. https://doi.org/10.3389/fpls.2017.00646

Maguire, R., \& Heckendorn, S. E. (2011). Laboratory procedures: Virginia Tech soil testing laboratory. Virginia Cooperative Extension, Blacksburg, VA. Retrieved from http://pubs.ext.vt.edu/452/452-881/ 452-881_pdf.pdf

Mehlich, A. (1976). New buffer $\mathrm{pH}$ method for rapid estimation of exchangeable acidity and lime requirement of soils. Communications in Soil Science and Plant Analysis, 7(7), 637-652. https://doi.org/10.1080/001036 27609366673

Molla, M., Solaiman, A., Jahiruddin, M., Mridha, M., \& Khanam, D. (2011). Influence of different doses of phosphorus in the presence of arbuscular mycorrhiza and Rhizobium on the growth and yield of mungbean. Bulletin of the Institute of Tropical Agriculture, Kyushu University, 34(1), 49-67.

Mondal, M., Puteh, A., Malek, M., Ismail, M., Rafii, M., \& Latif, M. (2012). Seed yield of mungbean (Vigna radiata (L.) Wilczek) in relation to growth and developmental aspects. The Scientific World Journal, 2012. https://doi.org/10.1100/2012/425168

Nair, R. M., Yang, R. Y., Easdown, W. J., Thavarajah, D., Thavarajah, P., Hughes, J. D. A., \& Keatinge, J. (2013). Biofortification of mungbean (Vigna radiata) as a whole food to enhance human health. Journal of the Science of Food and Agriculture, 93(8), 1805-1813. https://doi.org/10.1002/jsfa.6110 
Ndema, N., Etame, J., Taffouo, V., \& Bilong, P. (2010). Effects of some physical and chemical characteristics of soil on productivity and yield of cowpea (Vigna unguiculata L. Walp.) in coastal region (Cameroon). African Journal of Environmental Science and Technology, 4(3). https://doi.org/10.5897/AJEST09.160

Ntukamazina, N., Onwonga, R. N., Sommer, R., Mukankusi, C. M., Mburu, J., \& Rubyogo, J. C. (2017). Effect of excessive and minimal soil moisture stress on agronomic performance of bush and climbing bean (Phaseolus vulgaris L.). Cogent Food \& Agriculture, 3(1), 1373414. https://doi.org/10.1080/23311932. 2017.1373414

Oke, S. O., \& Eyitayo, D. L. (2010). Growth and yield response of cowpea (Vigna unguiculata L. Walp.) to soils from different fallow physiognomies in the rainforest zone of Nigeria. Acta Botanica Croatica, 69(2.), 291-297.

Paul, T., Mozumder, N., Sayed, M., Akhtaruzzaman, M., \& Akhtaruzzaman, M. S. M. (2011). Proximate compositions, minerals contents and determination of protease activity from green gram (Vigna radiata I. Wilczek). Bangladesh Res. J, 5, 207-213.

Peksen, E., Toker, C., Ceylan, F. Ö., Aziz, T., \& Farooq, M. (2015). Determination of promising high yielded mungbean (Vigna radiata (L.) Wilczek) genotypes under Middle Black Sea Region of Turkey. Anadolu Tarim Bilimleri Dergisi, 30(2), 169. https://doi.org/10.7161/anajas.2015.30.2.169-175

Peoples, M. B., \& Herridge, D. F. (1990). Nitrogen fixation by legumes in tropical and subtropical agriculture. Advances in Agronomy, 44, 155-223. https://doi.org/10.1016/S0065-2113(08)60822-6

Rahmianna, A., Adisarwanto, T., Kirchhof, G., \& So, H. (2000). Crop establishment of legumes in rainfed lowland rice-based cropping systems. Soil and Tillage Research, 56(1-2), 67-82. https://doi.org/10.1016/ S0167-1987(00)00123-9

Razzaque, M. A., Haque, M. M., Karim, M. A., \& Solaiman, A. R. M. (2016). Nitrogen fixating ability of mungbean genotypes under different levels of nitrogen application. Bangladesh Journal of Agricultural Research, 41(1), 163-171. https://doi.org/10.3329/bjar.v41i1.27681

Sharma, L., Priya, M., Bindumadhava, H., Nair, R., \& Nayyar, H. (2016). Influence of high temperature stress on growth, phenology and yield performance of mungbean [Vigna radiata (L.) Wilczek] under managed growth conditions. Scientia Horticulturae, 213, 379-391. https://doi.org/10.1016/j.scienta.2016.10.033

Sharma, P., \& Khanna, V. (2010). Influence of fluchloralin on growth of Rhizobium and PSB, symbiotic parameters and grain yield in mungbean. Journal of Food legumes, 23(1), 71-73.

Singh, G., Sekhon, H., Singh, G., Brar, J., Bains, T., \& Shanmugasundaram, S. (2011). Effect of plant density on the growth and yield of mungbean [Vigna radiata (L.) Wilczek] genotypes under different environments in India and Taiwan. International journal of agricultural research, 6(7), 573-583. https://doi.org/10.3923/ ijar.2011.573.583

Sriphadet, S., Lambrides, C. J., \& Srinives, P. (2007). Inheritance of agronomic traits and their interrelationship in mungbean (Vigna radiata (L.) Wilczek). Journal of Crop Science and Biotechnology, 10(4), 123-132.

Stajković-Srbinović, O., Kuzmanović, D., Mrvić, V., \& Knežević-Vukčević, J. (2011). Effect of bradyrhizobial inoculation on growth and seed yield of mungbean in Fluvisol and Humofluvisol. African Journal of Microbiology Research, 5(23), 3946-3957. https://doi.org/10.5897/AJMR11.689

Thomson, B., Siddique, K., Barr, M., \& Wilson, J. (1997). Grain legume species in low rainfall Mediterranean-type environments I. Phenology and seed yield. Field Crops Research, 54(2-3), 173-187. https://doi.org/10.1016/S0378-4290(97)00047-6

Travlos, I., \& Karamanos, A. (2006). Effects of soil texture on vegetative growth of tropical legume marama bean (Tylosema esculentum). Journal of Agronomy, 5(4), 609-612. https://doi.org/10.3923/ja.2006.609.612

Zaidi, A., Khan, M. S., \& Aamil, M. (2004). Bioassociative effect of rhizospheric microorganisms on growth, yield, and nutrient uptake of greengram. Journal of plant Nutrition, 27(4), 601-612. https://doi.org/10.1081/ PLN-120030370

Zhao, C., Jia, L., Wang, Y., Wang, M., \& McGiffen Jr, M. (2015). Effects of Different Soil Texture on Peanut Growth and Development. Communications in Soil Science and Plant Analysis, 46(18), 2249-2257. https://doi.org/10.1080/00103624.2015.1059845 


\section{Copyrights}

Copyright for this article is retained by the author (s), with first publication rights granted to the journal.

This is an open-access article distributed under the terms and conditions of the Creative Commons Attribution license (http://creativecommons.org/licenses/by/4.0/). 